\title{
Effects of Fertigation and Water Application Frequency on Yield, Water and Fertilizer Use Efficiency of Chili (Capsicum annuum L.).
}

\author{
S. Chanthai, and S. Wonprasaid*
}

\begin{abstract}
Drip irrigation is becoming popular for chili production in dry season. However, there is no suitable recommendation on water and nutrient application for chili under drip irrigation system. This experiment was conducted with the objective of evaluating the effects of fertigation, water application frequency and soil amendment on chili yield, fertilizer and water use efficiency under drip irrigation system. The treatments included three water application frequencies (1. at cumulative crop evapotranspiration $(\mathrm{ETc})=15 \mathrm{~mm}, 2 . \mathrm{ETc}=25 \mathrm{~mm}$ and $3 . \mathrm{ETc}=35$ $\mathrm{mm}$ ); two fertilization methods (fertigation and solid fertilizer application); and two soil amendments (with and without soil amendment). The results revealed that fertigation produced higher chili yield and fertilizer use efficiency than solid fertilizer application regardless of water application frequency and soil amendment. Without soil amendment, most frequent water application (ETc 15 $\mathrm{mm}$ ) resulted to the greatest yield and water use efficiency. With soil amendment, the impact of water application frequency on chili yield was small and all water application frequencies produced similar yield.
\end{abstract}

Index Terms - Chili, Drip irrigation, Fertigation, Water holding capacity, Plant water requirement.

\section{INTRODUCTION}

Chili is one of the important economic crops in Thailand. In 2013, the total growing area was about 24,000 ha [1]. It is grown during the dry season under irrigation system in the Northeast. The average yield in farmer fields is very low (5.81 $\mathrm{t} \mathrm{ha}^{-1}$ ) due to plant pests, low fertility soil and poor management practices. Drip irrigation as the most efficient irrigation method is recommended in this area. However, no information of proper water management such as the frequency and amount of water application is available.

High temperature and low humidity cause high crop evapotranspiration, therefore high amount of water has to be applied to meet the crop requirement. Since most of

the soils in this area are sandy with low organic matter content and low water holding capacity (WHC), if water is applied more than the WHC of the soil, there will be water and nutrients loss due to leaching.

Manuscript received May 9, 2016. This work was financial supported by Suranaree University of Technology Research Fund and National Research Council of Thailand.

S. Chanthai is a graduate student of Institute of Agricultural Technology, Suranaree University of Technology, Nakhon Ratchasima 30000, Thailand

S. Wonprasaid is with Institute of Agricultural Technology, Suranaree University of Technology, Nakhon Ratchasima 30000 Thailand
To prevent water and nutrient leaching, low amount of water (less than the WHC) has to be frequently applied.

To reduce the frequency of water application without any effect to the plant could be done by improve soil water holding capacity. Coir dust has been reported to improve soil water holding capacity, cation exchange capacity (CEC) and reduce bulk density of the soil [2] because it can absorb 8 times of water relative to its weight [3]. Incorporating coir dust at $2 \%$ of the soil weight was able to increase soil water holding capacity by $40 \%$ [4]. It has been successfully used as plant growth media for soilless culture. It could be adopted to use as soil amendment for the open crops such as chili if it is proved to be effective.

Besides water application, soil fertilizer application in this area is ineffective. Leaching is the main fertilizer loss as the soil is sandy with low water holding capacity. Fertigation with a suitable water application technique will help to improve both water and fertilizer use efficiency under this condition. There is limited information of water application and fertigation for chili in this area.

The objectives of this study were: 1) to determine the amount and the frequency of water application, 2) to study the effect of soil amendment (coir dust) on soil water holding capacity and its effect on water application frequency and 3) to compare the effects of fertigation and solid fertilizer application on fertilizer use efficiency, chili growth and yield.

\section{MATERIAL AND METHODS}

The field experiment was conducted in sandy loam soil of Chatturat soil series: Ct (Fine, mixed, active isohyperthermic Typic Haplustalfs), at Suranaree University of Technology, Nakhon Ratchasima, Thailand. The chemical and physical properties of experimental soil are shown in Table I. The available water holding capacity of the soil is $11.4 \%$ of volumetric water content.

The experimental design was split plot in RCBD with 3 replications. The main plots were the combination treatments of 2 methods of fertilizer application (soil application and fertigation) and 3 water application frequencies (at cumulative crop evapotranspiration (ETc) 15, 25 and $35 \mathrm{~mm}$ ). The sub plots were with and without soil amendments (coir dust). Coir dust (Table I) at the rate of $18.7 \mathrm{tha}^{-1}$ was incorporated at the same time of soil preparation. Soil was covered with black plastic sheet, and the inline drippers with $2 \mathrm{~L} \mathrm{~h}^{-1}$ of water discharge were installed under the plastic sheet. The plot size was $1 \times 5 \mathrm{~m}$. with a plant spacing of $0.5 \times 0.5 \mathrm{~m}$. After soil 
preparation, 30 days old chili seedlings cv. Super Hot was transplanted.

TABLE I

PROPERTIES OF EXPERIMENTAL SOIL (0-15 CM) AND COIR DUST

\begin{tabular}{lcc}
\hline Properties & Soil & Coir dust \\
\hline $\mathrm{pH}$ & 7.81 & 6.01 \\
$\mathrm{EC}\left(\mu \mathrm{S} \mathrm{m}^{-1}\right)$ & 113 & 1417 \\
Organic matter $(\%)$ & 1.28 & 59.6 \\
Organic carbon $(\%)$ & 0.74 & 34.7 \\
$\mathrm{~N}(\%)$ & 0.06 & 0.36 \\
$\mathrm{C}: \mathrm{N}$ & 12.1 & 96.1 \\
$\mathrm{P}\left(\mathrm{mg} \mathrm{kg}^{-1}\right)$ & 54.4 & $0.03(\%)$ \\
$\mathrm{K}\left(\mathrm{mg} \mathrm{kg}^{-1}\right)$ & 74.0 & $1.89(\%)$ \\
Field capacity (Vol\%) & 28.5 & 119 \\
Permanent wilting point $(\mathrm{Vol} \%)$ & 17.1 & 30.6 \\
Water holding capacity $(\mathrm{Vol} \%)$ & 11.4 & 88.3 \\
\hline
\end{tabular}

The amount of water to be applied each time was equivalent to the cumulative ETc in each treatment (Table II).
Therefore, the most frequent water application treatment (ETc $15 \mathrm{~mm}$ ) received the least amount of water each time, while the least frequent water application (ETc $35 \mathrm{~mm}$ ) received the largest amount of water. At the end of the experiment, all treatments received almost the same amount of water. The cumulative ETc 15-35 $\mathrm{mm}$ was used according to the soil available water holding capacity (11.4\%). The ETc of chilis was calculated by the following equation:

$$
\mathrm{ETc}=\mathrm{ETp} \times \mathrm{Kc}
$$

Where ETp is the potential evapotranspiration estimated based on the long-term average climatic data in this area [6]. Kc is the crop coefficient which is affected by several factors such as crop types, crop stages and cultural practices.

TABLE II

MONTHLY ETP, KC, ETC, AVERAGE WATER APPLICATION FREQUENCY AND AMOUNT OF WATER SUPPLY.

\begin{tabular}{|c|c|c|c|c|c|}
\hline Data & January & February & March & April & May \\
\hline $\mathrm{ETp}(\mathrm{mm} /$ day $)$ & 3.86 & 5.11 & 5.25 & 5.61 & 5.10 \\
\hline $\mathrm{Kc}$ & 0.67 & 0.67 & 0.67 & 0.67 & 0.67 \\
\hline $\mathrm{ETc}(\mathrm{mm} /$ day $)$ & 2.59 & 3.42 & 3.52 & 3.76 & 3.42 \\
\hline \multicolumn{6}{|c|}{ Water application frequency (days) } \\
\hline ETc $15 \mathrm{~mm}$. & 5 & 4 & 4 & 3 & 4 \\
\hline ETc $25 \mathrm{~mm}$. & 9 & 7 & 7 & 6 & 7 \\
\hline ETc $35 \mathrm{~mm}$. & 13 & 10 & 9 & 9 & 10 \\
\hline \multicolumn{6}{|c|}{ Water supply (mm/time) } \\
\hline ETc $15 \mathrm{~mm}$. & 13.0 & 13.7 & 14.1 & 11.3 & 13.7 \\
\hline ETc $25 \mathrm{~mm}$. & 23.3 & 23.9 & 24.6 & 22.6 & 23.9 \\
\hline ETc $35 \mathrm{~mm}$. & 33.7 & 34.2 & 31.7 & 33.8 & 34.2 \\
\hline \multicolumn{6}{|c|}{ Total water supply (mm/month) } \\
\hline ETc $15 \mathrm{~mm}$. & 80 & 96 & 109 & 112 & 106 \\
\hline ETc $25 \mathrm{~mm}$. & 80 & 96 & 109 & 112 & 106 \\
\hline ETc $35 \mathrm{~mm}$. & 80 & 96 & 109 & 112 & 106 \\
\hline
\end{tabular}

Rate of fertilizer application based on soil test [7] was 105-25$75 \mathrm{~kg} \mathrm{~N}, \mathrm{P}_{2} \mathrm{O}_{5}, \mathrm{~K}_{2} \mathrm{O}$ ha $^{-1}$. For solid fertilizer application, fertilizer was applied twice with a half rate at transplanting and the first flowering stage. For fertigation, fertilizer was applied weekly in equal amount from transplanting to the first flowering stage (10-12 times depending on water application frequency treatments). All treatments received the same amounts of $\mathrm{N}, \mathrm{P}$ and $\mathrm{K}$ at the end of fertigation.

Plant height, leaf area index (LAI), and dry matter were recorded at the first flowering stage while yield and yield component were recorded at harvest. Fertilizer use efficiency (FUE) was determined as a factor of total economic yield from all harvests by quantity of nutrient applied. The amounts of applied water were recorded throughout the growing period. Water use efficiency (WUE) was also estimated by dividing total economic yield with amounts of water applied.

All data were subjected to analysis of variance (ANOVA) using SPSS v. 13 for Window [8]. Means were compared by Duncan's Multiple Rang Test (DMRT).

\section{RESULTS AND DISCUSSION}

\section{Water Application}

Table II shows the values of ETp, Kc and ETc and the frequency of water application. The maximum value of ETc (3.76 mm day ${ }^{-1}$ ) was recorded in April which is the hottest and driest month in this area. The frequency of water application estimated from the cumulative ETc was found to be most frequent in April in all treatments. The average water application frequency of treatment ETc $15 \mathrm{~mm}$ ranged between 3-5 days while those of treatment ETc $35 \mathrm{~mm}$ ranged between 9-13 days. Total amounts of water application in all treatments were similar at about $500 \mathrm{~mm}$.

\section{Growth, Yield and Yield Components}

In general, plant growth (plant height, LAI, dry matter and $\%$ light interception) responded to fertilization method, water application frequency and soil amendment (Table III). Fertigation produced taller plant, higher LAI, and dry matter than solid fertilizer application. The most frequent water 
application (ETc $15 \mathrm{~mm}$ ) produced the greatest growth parameters while soil amendment improved all plant growth parameters recorded.

Fertigation also gave higher weight of 100 fruits and total yield than soil application (Table IV). Similar to plant growth, the most frequent water application (ETc $15 \mathrm{~mm}$ ) gave the highest weight of 100 fruits $(218 \mathrm{~g})$ and total yield $(13.58 \mathrm{t}$ $\left.\mathrm{ha}^{-1}\right)$, and coir dust incorporation produced greater weight of 100 fruits $(215 \mathrm{~g})$ and yield $\left(10.37 \mathrm{t} \mathrm{ha}^{-1}\right)$ than the control.

There were no significant interactions among fertilization method and water application frequency and soil amendment on chili yield but a significant interaction existed between water application frequency and soil amendment (Fig. 1a). Without soil amendment water application frequency had a large effect on chili yield, while with soil amendment it had a little effect. This implied that soil amendment could reduce the water application frequency for chili production in the sandy loam soil.

TABLE III

Plant Height, L EAF AREa Index (LAI) AND DRy MatTer OF ChILI.

\begin{tabular}{lccc}
\hline Treatment & $\begin{array}{c}\text { Plant height } \\
(\mathrm{cm})\end{array}$ & LAI & $\begin{array}{c}\text { Dry matter } \\
\left(\mathrm{g} \mathrm{plant}^{-1}\right)\end{array}$ \\
\hline $\begin{array}{l}\text { Fertilizer application } \\
\text { Fertigation }\end{array}$ & 79.63 & 2.74 & 21.47 \\
$\quad$ Solid application & 77.83 & 2.63 & 19.38 \\
\hline Water application frequency & & & \\
ETc 15 mm & 81.12 & $3.29 \mathrm{a}$ & $24.51 \mathrm{a}$ \\
ETc 25 mm & 78.52 & $2.58 \mathrm{~b}$ & $20.35 \mathrm{~b}$ \\
ETc 35 mm & 76.56 & $2.18 \mathrm{c}$ & $16.41 \mathrm{c}$ \\
\hline Soil amendment & & & \\
With & 80.01 & $3.04 \mathrm{a}$ & $22.56 \mathrm{a}$ \\
Without & 77.45 & $2.33 \mathrm{~b}$ & $18.29 \mathrm{~b}$ \\
\hline \% CV. & 4.51 & 6.85 & 11.50 \\
\hline
\end{tabular}

In a column within each factor, means followed by a common letter are not significantly different at $5 \%$ level by DMRT

TABLE IV

YIELD AND YIELD COMPONENTS OF CHILI.

\begin{tabular}{|c|c|c|c|}
\hline Treatment & $\begin{array}{l}\text { Yield } \\
\left(\mathrm{t} \mathrm{ha}^{-1}\right)\end{array}$ & $\begin{array}{l}\text { Weight of } 100 \text { fruits } \\
(\mathrm{g})\end{array}$ & $\begin{array}{c}\text { Rotten fruits } \\
(\%)\end{array}$ \\
\hline \multicolumn{4}{|l|}{ Fertilizer application } \\
\hline Fertigation & $12.09 \mathrm{a}$ & $206 a$ & $2.19 b$ \\
\hline Solid application & $11.48 b$ & $182 \mathrm{~b}$ & $2.32 \mathrm{a}$ \\
\hline \multicolumn{4}{|c|}{ Water application frequency } \\
\hline ETc $15 \mathrm{~mm}$ & $13.58 \mathrm{a}$ & $218 \mathrm{a}$ & $2.27 \mathrm{ab}$ \\
\hline ETc $25 \mathrm{~mm}$ & $12.92 b$ & $207 b$ & $2.18 \mathrm{~b}$ \\
\hline ETc $35 \mathrm{~mm}$ & $8.87 \mathrm{c}$ & $156 \mathrm{c}$ & $2.33 \mathrm{a}$ \\
\hline \multicolumn{4}{|l|}{ Soil amendment } \\
\hline With & $13.21 \mathrm{a}$ & $215 \mathrm{a}$ & 2.26 \\
\hline Without & $10.37 \mathrm{~b}$ & $173 b$ & 2.26 \\
\hline$\% \mathrm{CV}$ & 5.05 & 5.10 & 6.24 \\
\hline
\end{tabular}

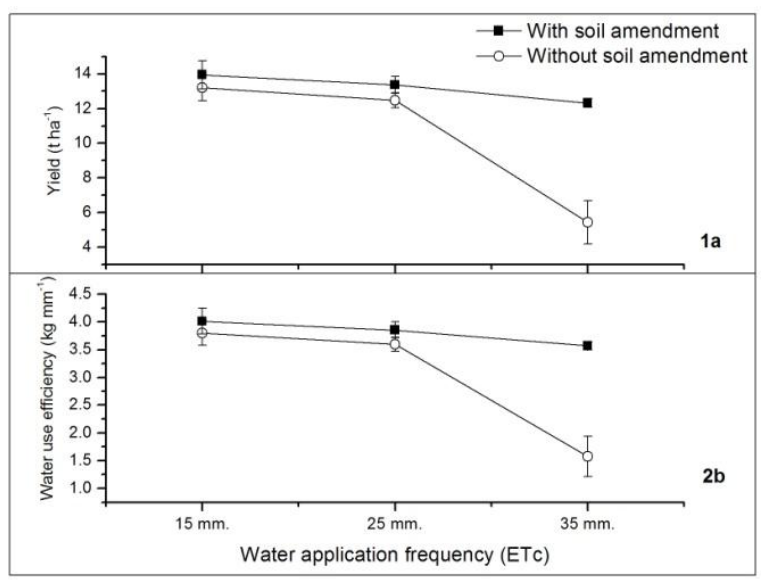

Fig. 1. Interaction between water application frequency and soil amendment on chili yield (a) and water use efficiency (b)

\section{Water And Fertilizer Use Efficiency}

As the amounts of applied water and fertilizer were the same in all treatments, the WUE and FUE responded exactly the same to fertilization, water application frequency and soil amendment as chili yield. The values of WUE ranged between $2.99-3.90 \mathrm{~kg} \mathrm{~m}^{-3}$ which was in the range of WUE reported by the other study with similar climatic conditions [9].

There were no significant interactions among fertilization method and water application frequency and soil amendment on WUE, but a significant interaction existed between water application frequency and soil amendment (Fig. 1b).

Since the FUE in this study was calculated as total economic yield divided by amount of applied fertilizer regardless of the soil nutrients, its values were higher than the values reported from the literatures [10], [11].

Effect of fertilizer application methods on FUE was associated to nutrient uptake. Since dry matter was also greater in the fertigation treatment, it can be implied that the nutrient uptake was greater under the fertigation method. The beneficial effects of fertigation over solid fertilizer application have been reported [12], [13]. Badr et al., 2010 [11] reported that $\mathrm{N}$ and $\mathrm{K}$ applied via fertigation were confined to the root zone, while they moved beyond the root zone when they were applied as solid fertilizer. They also reported that the mobility of $\mathrm{P}$ was greater in the root zone following its application through fertigation compared to a solid fertilizer application. They concluded that chili plants were able to utilize applied nutrients more efficiently in fertigation system than with solid fertilizer application. In this study, the downward nutrients movement was not examined. However, the more nutrient uptake by plants under the fertigation system implied that nutrients were more available at the root zone of chili plants during the growing period under the fertigation system. 
TABLE V

WATER USE EFFICIENCY (WUE) AND FERTILIZER USE EFFICIENCY (FUE) OF CHILI.

\begin{tabular}{|c|c|c|c|c|}
\hline \multirow{2}{*}{ Treatment } & \multirow{2}{*}{$\begin{array}{c}\text { WUE } \\
\left(\mathrm{kg} \cdot \mathrm{mm}^{-1}\right)\end{array}$} & \multicolumn{3}{|c|}{$\begin{array}{l}\text { FUE } \\
\left(\mathrm{kg} \mathrm{kg}^{-1}\right)\end{array}$} \\
\hline & & $\mathrm{N}$ & $P$ & $\mathrm{~K}$ \\
\hline \multicolumn{5}{|l|}{ Fertilizer application } \\
\hline Fertigation & $3.43 \mathrm{a}$ & $3.36 \mathrm{a}$ & $120 \mathrm{a}$ & $13.4 \mathrm{a}$ \\
\hline Solid application & $3.31 \mathrm{~b}$ & $3.18 \mathrm{~b}$ & $114 \mathrm{~b}$ & $12.7 \mathrm{~b}$ \\
\hline \multicolumn{5}{|c|}{ Water application frequency } \\
\hline ETc $15 \mathrm{~mm}$ & $3.90 \mathrm{a}$ & $3.77 \mathrm{a}$ & $135 \mathrm{a}$ & $15.0 \mathrm{a}$ \\
\hline ETc $25 \mathrm{~mm}$ & $3.72 b$ & $3.58 \mathrm{~b}$ & $129 b$ & $14.3 \mathrm{~b}$ \\
\hline ETc $35 \mathrm{~mm}$ & $2.57 \mathrm{c}$ & $2.46 \mathrm{c}$ & $88.0 \mathrm{c}$ & $9.85 \mathrm{c}$ \\
\hline \multicolumn{5}{|l|}{ Soil amendment } \\
\hline With & $3.81 \mathrm{a}$ & $3.66 \mathrm{a}$ & $132 \mathrm{a}$ & $14.6 \mathrm{a}$ \\
\hline Without & $2.99 \mathrm{~b}$ & $2.88 \mathrm{~b}$ & $103 b$ & $11.5 \mathrm{~b}$ \\
\hline$\% \mathrm{CV}$ & 5.08 & 5.08 & 5.05 & 5.05 \\
\hline
\end{tabular}

In a column within each factor, means followed by a common letter are not significantly different at $5 \%$ level by DMRT

\section{Soil Physical And Chemical Properties}

The soil physical and chemical properties analyzed after the last harvesting were shown in Tables VI and VII. Soil permeability and available water holding capacity (AWHC) significantly increased, while soil bulk density decreased with the soil amendment compared to the control. Plant AWHC was defined as the difference between water content at field capacity and permanent wilting point. Fig. II shows the relationship between water extraction tension and soil water content. It can be seen that at all extraction tensions, the soil water contents were greater in the soil with coir dust incorporation than in the control. However, the differences of water content between the two treatments were greater at the tension level associated with the field capacity $(9.8 \mathrm{kPa})$ than with the permanent wilting point $(1569.6 \mathrm{kPa})$. This result led to the increase in AWHC of the soil with coir dust incorporation. The resulted was similar to the results reported by Thampan (1981) [4] who found that coir dust incorporation with $2 \%$ of soil weight improved AWHC by $40 \%$.

The interaction between water application frequency and soil amendment on yield and WUE (Fig.1a and 1b) was attributed to the improvement of AWHC by soil amendment. Without soil amendment, the available water holding capacity (AWHC) of the soil is low (11.4-11.6\%) (Tables I and VI). In treatment of water application at $35 \mathrm{~mm}$, water would percolate through to about $80 \mathrm{~cm}$ depth while water application at $15 \mathrm{~mm}$, it would percolate through to $35 \mathrm{~cm}$. Therefore, for treatment of ETc $35 \mathrm{~mm}$. (the least frequent application of water, 9-13 days), some amount of applied water would move deeper than chili root zone and that would reduce the amount of available water for chilli. Moreover, the downward movement of water could leach some plant nutrients out of the root zone which led to low FUE and productivity of chili in this treatment. On the other hand, with soil amendment, AWHC increased to $17.4 \%$ (Table VI). Water application at $35 \mathrm{~mm}$, water would percolate through to only $40 \mathrm{~cm}$ depth which was still inside the chili root zone. There were no water and fertilizer loss.

There were little effects of fertilizer application method and water application frequency on soil chemical properties and plant nutrients except for P (Table VII). Soil P was greater in the solid fertilizer application than in the fertigation treatment, suggesting that more $\mathrm{P}$ was removed by plants under the fertigation system. Since P mobility in the soil is normally limited, fertigation with solution $\mathrm{P}$ could facilitate its movement to the roots and enhance P uptake by the plants. This result is in agreement with the result of Badr et al., (2010) [11].

TABLE VI

SOIL PHYSICAL PROPERTIES AFTER HARVESTING.

\begin{tabular}{|c|c|c|c|}
\hline Treatment & $\begin{array}{r}\text { Permeability } \\
\left(\mathrm{mm} \mathrm{h}^{-1}\right)\end{array}$ & $\begin{array}{c}\text { Bulk density } \\
\left(\mathrm{g} \mathrm{cm}^{-3}\right)\end{array}$ & $\begin{array}{c}\text { AWHC } \\
(\%)\end{array}$ \\
\hline \multicolumn{4}{|l|}{ Fertilizer application } \\
\hline Fertigation & 64.69 & 1.23 & 15.06 \\
\hline Solid application & 61.69 & 1.18 & 13.93 \\
\hline \multicolumn{4}{|c|}{$\begin{array}{l}\text { Water application } \\
\text { frequency }\end{array}$} \\
\hline ETc $15 \mathrm{~mm}$ & 70.74 & 1.16 & 14.89 \\
\hline ETc $25 \mathrm{~mm}$ & 70.57 & 1.26 & 14.46 \\
\hline ETc $35 \mathrm{~mm}$ & 48.26 & 1.20 & 14.13 \\
\hline \multicolumn{4}{|l|}{ Soil amendment } \\
\hline With & $85.79 \mathrm{a}$ & $0.97 \mathrm{~b}$ & $17.39 \mathrm{a}$ \\
\hline Without & $40.58 b$ & $1.44 \mathrm{a}$ & $11.60 \mathrm{~b}$ \\
\hline$\% \mathrm{CV}$ & 16.62 & 9.12 & 32.83 \\
\hline
\end{tabular}

In a column within each factor, means followed by a common letter are not significantly different at $5 \%$ level by DMRT

TABLE VII

SOIL CHEMICAL PROPERTIES AFTER HARVESTING.

\begin{tabular}{|c|c|c|c|c|c|c|}
\hline Treatment & $\mathrm{pH}$ & $\begin{array}{c}\mathrm{EC} \\
\left(\mu \mathrm{S} \mathrm{m}^{-1}\right)\end{array}$ & $\begin{array}{l}\mathrm{OM} \\
(\%)\end{array}$ & $\begin{array}{c}\text { Available P } \\
\left(\mathrm{mg} \mathrm{kg}^{-1}\right)\end{array}$ & $\begin{array}{c}\text { Exchangeable K } \\
\left(\mathrm{mg} \mathrm{kg}^{-1}\right)\end{array}$ & $\begin{array}{c}\text { Exchangeable Ca } \\
\left(\mathrm{mg} \mathrm{kg}^{-1}\right)\end{array}$ \\
\hline \multicolumn{7}{|l|}{ Fertilizer application } \\
\hline Fertigation & $6.26 \mathrm{a}$ & $55.06 \mathrm{~b}$ & 1.23 & $9.77 \mathrm{~b}$ & $57.57 \mathrm{~b}$ & $723.2 b$ \\
\hline Solid application & $5.93 \mathrm{~b}$ & $68.04 \mathrm{a}$ & 1.02 & $16.19 \mathrm{a}$ & $71.84 \mathrm{a}$ & $829.2 \mathrm{a}$ \\
\hline \multicolumn{7}{|c|}{ Water application frequency } \\
\hline ETc $15 \mathrm{~mm}$ & 6.14 & 57.59 & 1.09 & $10.19 b$ & 60.73 & 733.4 \\
\hline ETc $25 \mathrm{~mm}$ & 6.19 & 67.10 & 1.21 & $10.40 \mathrm{~b}$ & 69.44 & 777.1 \\
\hline ETc $35 \mathrm{~mm}$ & 5.97 & 59.95 & 1.08 & $18.34 \mathrm{a}$ & 63.94 & 818.1 \\
\hline \multicolumn{7}{|l|}{ Soil amendment } \\
\hline With & 6.00 & 62.91 & $1.55 \mathrm{a}$ & $10.38 b$ & $74.26 \mathrm{a}$ & $813.7 \mathrm{a}$ \\
\hline Without & 6.19 & 60.19 & $0.71 \mathrm{~b}$ & $15.58 \mathrm{a}$ & $55.14 b$ & $738.2 b$ \\
\hline$\% \mathrm{CV}$ & 4.3 & 22.38 & 40.75 & 33.74 & 41.17 & 9.11 \\
\hline
\end{tabular}

In a column within each factor, means followed by a common letter are not significantly different at $5 \%$ level by DMRT 


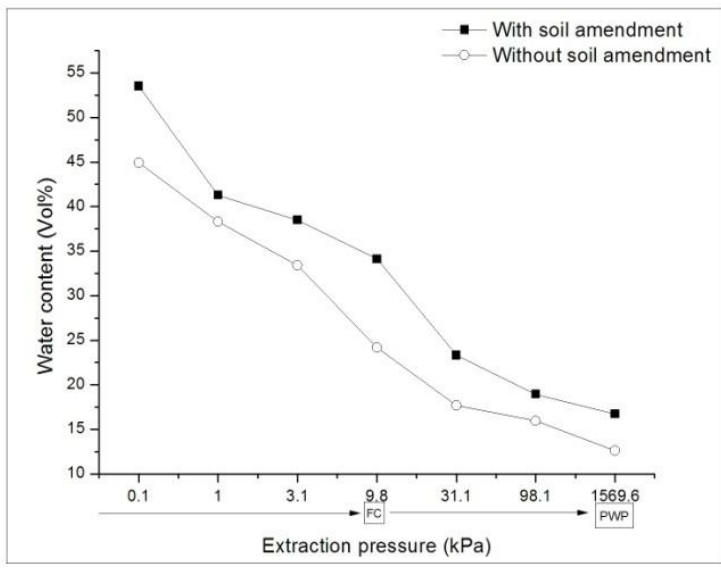

Fig. 2. Effects of soil amendment on water holding capacity in experimental soil.

\section{CONCLUSION}

The present study indicated that under hot and dry conditions with coarse texture soil, more frequent water application (4-5 days) with less amount of each application was an appropriate practice for chili production. However, with the incorporation of soil amendment (coir dust) that could improve the soil available water holding capacity, the frequency of water application can be reduced (9-13 days) with little effect on chili. Fertigation improved all plant growth and yield components compared to soil application. Its effect on plant growth and yield was attributed to greater nutrient uptake and fertilizer use efficiency.

\section{ACKNOWLEDGEMENT}

The authors wish to acknowledge the Suranaree University of Technology Farm for providing the experimental field and materials.

\section{REFERENCES}

[1] Department of Agricultural Extension. "Statistical information of economic crop production" [Online]. http://www.oae.go.th. 2014.

[2] D. C. Cresswell, "Coir dust-a viable alternative to peat" Biological and Chemical Research Institute, vol. 25, pp. 5-11, 2006.

[3] B. C. Walpola, and S. D. Wanniarachchi, "Microbial respiration and nitrogen mineralization in soil amendment with different proportions of vermi compost and coir dust" Bangladesh J. Agril. Res., vol. 34, pp. 537-543, 2009.

[4] P. K. Thampan, "Hand Book of Coconut Pal," Oxford and IBH Publishing, Ed. New York, 1981.

[5] R. G. Allen, L. S. Pereira, D. Raes, and M. Smith, "Crop evapotranspiration. Guidelines for computing crop water requirements," FAO, Ed. Rome, 1998.

[6] D. Thongaram, W. Tangsakul, N. Jirachewee, and I. Nuntagij, "Technology of water supply," Thanganprim Co. Ltd., Ed. Bangkok, 2002.

[7] Department of Agricultural, "The use of fertilizers on crops," Federation of Agricultural Cooperatives of Thailand, Ed. Bangkok, 2005.

[8] R. Levesque, and SPSS Inc. "SPSS programming and Data Management, 3 nd Edition," SPSS Institute, Ed. United State of America, 2006.

[9] E. Antony, and R. B. Singandhupe, "Impact of drip and surface irrigation on growth, yield and WUE of capsicum (Capsicum annum L.)" Agricultural Water Management. J., vol. 65, pp. 121-132, 2004.
[10] S. I. Shedeed, S. M. Zaghloul, and A. A. Yassen, "Effect of method and rate of fertilizer application under drip irrigation on yield and nutrient uptake by tomato" Ozean J. Applied Sciences., vol. 2, pp. 139-147, 2009.

[11] M. A. Badr, S. D. Abou Hussein, and W. A. EI-Tohamy, "Nutrien uptake and yield of tomato under various method of fertilizer application and levels of fertigation in arid lands" Gesunde Pflanzen. J., vol. 62, pp. 11-19, 2010. http://dx.doi.org/10.1007/s10343-010-0219-5

[12] S. J. Locascio, G. Hochmuth, F. M. Rhoads, S. M. Olson, A. G. Smajstrla, and E. A. Hanlon, "Nitrogen and potassium application scheduling effect on drip-irrigated tomato yield and leaf tissue analysis" J. Hort. Sci., vol. 32, pp. 230-235, 1997.

[13] S. S. Hebbar, B. K. Ramachandrappa, H. V. Nanjappa, and M. Prabhakar, "Studies on NPK drip fertigation in field grown tomato (Lycopersicon esculentum Mill.)" J. Europ Agronomy., vol. 21, pp. 117-127, 2004.

http://dx.doi.org/10.1016/S1161-0301(03)00091-1 